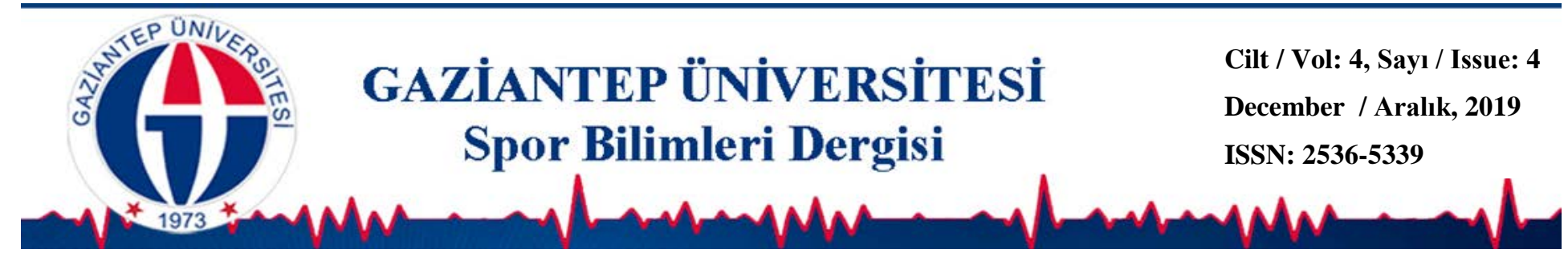

\title{
Bireylerin Spor Yapma Durumlarıyla, Benlik Saygıları ve Mutluluk Düzeyleri Arasındaki Ilişkisinin İncelenmesi
}

\author{
Kutluhan DEMiR ${ }^{1 *}$ Savaş DUMAN ${ }^{2}$ \\ ${ }^{1}$ Aydın Adnan Menderes Üniversitesi, Çine Meslek Yüksekokulu, AYDIN \\ ${ }^{2}$ Aydın Adnan Menderes Üniversitesi, Spor Bilimleri Fakültesi, AYDIN
}

\section{DOI: 10.31680/gaunjss.567126}

Orijinal Makale / Original Article

Geliș Tarihi / Received: 17.05.2019

\section{Öz}

Bireylerin mutlu olmaları sonucunda, kendileri ile barışık olmaları ve dolayısı ile bu bireylerin kendilerini beğenmeleri arasındaki bağlantı sıkça araştırmalara konu olarak literatürde yerini almaktadır. Birçok çalışmada belirtildiği üzere mutluluk hormonu olan serotonin salınımını hızlandıran etkenlerden biri egzersizdir. Egzersizin yani sporun serotonin salınımı vasıtasıyla bireylerin kendini mutlu hissetmesi, kendini beğenme yani benlik saygıları ile arasındaki ilişkinin açığa çıkarılması, sporun insan psikolojisine olumlu katkısının vurgulanması açısından önem taşımaktadır. Araştırmamız, bireylerin spor yapma durumlarıyla; benlik saygıları ve mutluluk düzeyleri arasındaki ilişkinin incelenmesi amacıyla gerçekleştirilmiştir. Bu amaçla, 2018 yılı Ekim ve Kasım ayları arasında sosyal medya üzerinden "Google form üzerinden online anket şeklinde hazırladığımız anketi online link olarak" dağıtılarak cevap kabul edilen ankete, 238'i spor yapan, 282'si spor yapmayan ve 224 erkek, 296 kadın olmak üzere toplamda 520 kişi katılım sağlamıştır. Verilerin toplanmasında, Rosenberg (1965) tarafından geliştirilen ve Türkiye'deki güvenilirlik ve geçerlilik çalışmaları Çuhadaroğlu (1986) tarafından yapılan 5'i olumlu, 5'i olumsuz ifadelerden oluşan 10 ifadeli "Rosenberg Benlik Saygısı Ölçeği- Kısa Formu (RBSÖ-KF)" ve Demirci (2017) tarafından geliştirilen ve 6 ifadeden oluşan "Mutluluk Ölçeği” kullanılmıştır. Mutluluk ölçeği tek faktör olarak ölçülürken, Rosenberg benlik saygısı ölçeği olumlu ifadelerden oluşan, olumsuz ifadelerden oluşan ve tüm ifadeleri içeren 3 farklı ölçek ortalaması ile ölçülmüştür. T-testi, tek yönlü varyans analizi (ANOVA) ve Post-hoc testleri kullanılarak yapılan istatistik analizler (SPSS) sonucunda örneklemi oluşturulan bireylerin: medeni durumu, spor yapma durumu, spor yapma süreleri, sporda profesyonellik düzeyleriyle benlik saygısı ve mutluluk düzeylerinin her ikisi arasında; yaş aralığı ve gelir düzeyleri ile benlik saygısı düzeyleri arasında; eğitim seviyeleri ve çalışma durumları ile benlik saygısını ölçen olumsuz ifadeler ile toplam benlik saygısı düzeyleri arasında anlamlı ilişki olduğu tespit edilmiştir. Bulgular sonucunda, bireylerin benlik saygısı ve mutluluk düzeylerinin, spor yapan bireylerde spor yapmayanlara göre daha yüksek olduğu ve dolayısıyla sporun bireylere benlik saygısı ve mutluluk düzeyleri üzerinden psikolojilerine olumlu katkılar yaptığı söylenebilmektedir.

Anahtar Kelimeler: Mutluluk, Benlik Saygısı, Spor

\footnotetext{
* Sorumlu Yazar: Kutluhan DEMİR

E-mail: kutluhan.demir@adu.edu.tr

${ }^{1}$ Bu çalışma 7-9 Aralık 2018 tarihinde “1.Uluslararası Battalgazi Multidisipliner Çalışmalar Kongresi”nde sözel bildiri olarak sunulmuştur.
} 


\title{
Examining the Relation Between Self-Esteem and Happiness Level Considering the Condition of People Doing Exercise
}

\begin{abstract}
As a result of the happiness of the individuals, the connection between being at peace with themselves and getting above themselves is often in the literature as the subject of research. As stated in many studies, a hormone of happiness is one of the factors that accelerate the release of serotonin, which is exercise. With the help of the release of serotonin, it is important to emphasize making the individuals feel happy, being full of themselves, revealing the reletionship between self-esteem in the terms of the positive contribution of sports to human psychology on the sports. In this sense, the aim of our research is related to examining the relationship between self-esteem and happiness levels on individuals with the status of making sports. For this purpose, the questionnaire was distributed on'online survey as a questionnaire prepared on the google form as an online link " via social media between October and November 2018. According to the answers of it, a total of 520 people participation is ensured; 238 of which are engaged in sports and 282 non-sports and 224 men, 296 women. In data collection, developed by Rosenberg (1965) and the reliability with validity studies carried out by Çuhadaroğlu (1986) in Turkey, consisting of 5 positive and 5 negative statements, ten worded "Rosenberg Self-Esteem Scale Short Form" (SF-RSES) and "Happiness Scale" which was developed by Demirci (2017) and composed of 6 expressions was used. While the happiness scale was measured as a single factor, the Rosenberg self-esteem scale was measured with the average of 3 different scales, that is including positive expressions and negative expressions. T-test, one-way of variance (ANOVA) and post-hoc tests using statistical analysis (SPSS) as a result of the sample created individuals: The releationship is associated with marital status, sporting status, sporting time, the level of professionalism in sport, self-esteem and between both of happiness levels; between age range and income levels with self-esteem levels; between the levels of education and the working condition among negative expressions measuring self-esteem and a total self-esteem levels. In consequence of the findings, it could be said that individuals' self-esteem and happiness levels are higher than those who do not sports; therefore, sports makes positive contributions to individuals' psychology in terms of self-esteem and happiness levels.
\end{abstract}

Keywords: Happiness, Self-Esteem, Sports.

\section{Giriş}

Spor; kişisel veya toplu oyunlar biçiminde yapılan genellikle yarışmaya yol açan, bazı kurallara göre uygulanan beden hareketlerinin tümüdür (Çoknaz, 1998). Sporun fiziksel ve ruhsal olarak insan organizması üzerinde birçok fayda sağladığı bilinmektedir. Bireyin benliğine ulaşmasında doğru kişilik ve karakter oluşmasında sporun şüphesiz etkisi bulunmaktadır. Benlik kavramı, bir bireyin kendini algılama şekli, kim ve ne olduğuna, kimliğine ilişkin düşüncesidir. Kısaca kişinin kendinden ve sahip olduğu tüm özelliklerden memnun olması diye adlandırılabilir. Rosenberg'e (1979) göre, benlik saygısı, bireyin kendine karşı göstermiş olduğu olumlu ve olumsuz davranışlar sonucunda sergilemiş olduğu tutumlar yüksek benlik ve/veya düşük benlik durumlarını ifade eder. Benlik saygısı yüksek olan bireyler yaşam süresi içerisinde daha pozitif, mutlu ya/ya da olumlu düşünsel, duygusal hareketler (tavırlar) sergilerken, düşük benlik saygısına sahip olan bireylerde ise daha çok negatif, mutsuz hareketler (tavırlar) ve olumsuz düşünceler ağır basmaktadır. Guindon (2009)'a göre ise; benlik saygısı, bireyin tüm yaşamsal sürecine entegre olmuş iyi olma haliyle yakından ilişkilidir. Alkol, stres, sigara, kaygı, mutsuzluk vb. psikolojik etkenler ise düşük benlik saygısı ile yakından ilişkilidir. Benlik kurguları ve mutluluk arasındaki ilişkiyi inceleyen az sayıda çalışma olmakla birlikte bireyci toplumlardaki 
ortalama mutluluk seviyesinin toplulukçu toplumlara oranla daha yüksek olduğu bilinmektedir (Diener ve ark., 2003). Mutluluk, iyi ve kaliteli bir yaşam için önemli olması, olumlu kişiler arası ilişkilere katkı sağlaması, başarıyı ve motivasyonu artırması ve fiziksel ve ruhsal açıdan sağlıklı bir yaşamı desteklemesi nedeniyle dünyanın pek çok yerinde bireylerin hedef olarak belirlediği, ruh sağlığı uzmanlarınınsa danışanlarında teşvik etmeye çalıştığı bir yaşantıdır (Diener ve Chan, 2011; Jacobs ve Lyubomirsky, 2012). Mutluluğu gelişim odaklı olarak tanımlayan diğer yaklaşıma göre ise mutluluk, bireyin kendini gerçekleştirmesi, potansiyelini ve güçlerini en iyi şekilde kullanması, yaşamda anlam bulması ve erdemli bir yaşam sürmesi ile yakından ilişkilidir (Koydemir ve Mısır, 2015). Mutlu insanların daha az mutlu insanlardan yaşam olaylarını yorumlamaları, değerlendirmeleri ve onlara tepkide bulunma biçimleri açısından farklılık gösterdikleri belirtilmiştir (Lyubomirsky, 2001).

Bu çalışmada, bireylerin spor yapma durumlarıyla, benlik saygıları ve mutluluk düzeyleri arasındaki ilişkinin incelenmesi amaçlanmıştır.

\section{Yöntem}

\section{Araştırma Modeli}

Çalışmamızda spor yapan ve yapmayan bireylerin benlik saygısı ve mutluluk düzeyleri arasındaki ilişkinin incelenerek belirlenmesi amacıyla betimsel tarama modeli kullanılmıştır.

\section{Araştırma Grubu}

Çalışmanın araştırma grubunu, Ekim ve Kasım 2018 tarihlerinde sosyal medya üzerinde ulaşılan \%45,8 ile 238'i spor yapan, \%54,2 ile 282'si spor yapmayan ve $\% 43,1$ ile 224 erkek, \% 56,9 ile 296 kadın olmak üzere toplam 520 gönüllü katılımcı oluşturmuştur.

\section{Veri Toplama Araçları}

Araştırmada veri toplama aracı olarak araştırmacılar tarafından oluşturulan "Kişisel Bilgi Formu”, Rosenberg (1965) tarafından geliştirilen ve Türkiye'deki güvenilirlik ve geçerlilik çalışmaları Çuhadaroğlu (1986) tarafından yapılan ve 5’i olumlu, 5'i olumsuz toplam 10 ifadeden oluşan "Rosenberg Benlik Saygısı ÖlçeğiKısa Formu (RBSÖ-KF)" ve Demirci (2017) tarafından geliştirilen ve 6 ifadeden oluşan "Mutluluk Ölçeği” kullanılmıştır 


\section{Rosenberg Benlik Saygısı Ölçeği- Kısa Formu (RBSÖ-KF)}

Rosenberg (1965) tarafından geliştirilen "Rosenberg benlik saygısı ölçeği kısa formu (RBSÖ-KF)"nun Türkiye'deki güvenilirlik ve geçerlilik çalışmaları Çuhadaroğlu (1986) tarafından yapılmıştır. Ölçek; olumlu ifadelerden oluşan, olumsuz ifadelerden oluşan ve tüm ifadeleri içeren 3 farklı ölçek ortalaması ile ölçülmüştür. Ölçekte 5'i olumlu, 5'i olumsuz olmak üzere toplam 10 soru bulunmaktadır. Olumlu ve olumsuz yüklü maddeler ardışık olarak sıralanmaktadır. 1, 2, 4, 6 ve 7 numaralı maddeler olumlu; 3, 5, 8, 9 ve 10 numaralı maddeler olumsuz yüklüdür. Rosenberg benlik saygısı ölçeği 63 maddeden ve on iki alt alandan oluşur ve ilk on maddesi benlik saygısını ölçmektedir. RBSÖ-KF' nin Türkçe geçerlilik ve güvenilirlik çalışmasında 01 puan yüksek benlik saygısı, 2-4 puan orta benlik saygısı, 5-6 puan düşük benlik saygısı olarak puanlandırılmıştır. Ölçek puanlamasında düşük puan, benlik saygısının yüksekliğini; yüksek puan, benlik saygısının düşüklüğünü göstermektedir.

\section{Mutluluk Ölçeği}

Araştırmada mutluluk ölçümünde referans kabul edilen 6 ifadeden ve tek alt boyuttan oluşan ölçek DEMiRCi tarafından 2017 yılında geliştirilmiş ölçek kullanılmıştır. DEMiRCi Ölçeğin iç tutarlıık katsayısının (Cronbach's Alpha) 0,83 olduğunu belirtmiştir, bizim çalışmamızda cronbach's Alpha güvenirlilik değeri 0.90 olarak bulunmuştur ve verilerin güvenirliği oldukça yüksektir. Ayrıca araştırmada bir diğer veri toplamı aracı olarak araştırmacılar tarafından oluşturulan "Kişisel Bilgi Formu" kullanılmıştır.

\section{Verilerin Analizi}

İstatistiksel analiz uygulaması olan SPSS 21.0 paket programı ile gerçekleştirilen t-testi, tek yönlü varyans analizi (Anova) ve post-hoc testleri kullanılarak analizler yapılmış ve sonuçlar elde edilmiştir. 
Demir, K., ve Duman, S. (2019). Bireylerin Spor Yapma Durumlarıyla, Benlik Saygıları ve Mutluluk Düzeyleri Arasındaki İlişkisinin İncelenmesi. Gaziantep Üniversitesi Spor Bilimleri Dergisi, 4(4), 437-449.

\section{Bulgular}

Tablo 1. Demografik Özellikler

\begin{tabular}{|c|c|c|c|}
\hline Değişkenler & Gruplar & $\mathbf{N}$ & $\%$ \\
\hline \multirow[t]{2}{*}{ Cinsiyet } & Erkek & 224 & 43,1 \\
\hline & Kadın & 296 & 56,9 \\
\hline \multirow[t]{3}{*}{ Yaş } & $18-21$ & 293 & 56,3 \\
\hline & $22-25$ & 119 & 22,9 \\
\hline & 26 yaş ve üzeri & 108 & 20,8 \\
\hline \multirow[t]{2}{*}{ Medeni Durum } & Evli & 73 & 14,0 \\
\hline & Bekâr & 447 & 86,0 \\
\hline \multirow[t]{3}{*}{ Eğitim Durumu } & Lise ve öncesi & 48 & 9,2 \\
\hline & Üniversite & 448 & 86,2 \\
\hline & Lisansüstü & 24 & 4,6 \\
\hline \multirow[t]{7}{*}{ Aylık Gelir } & 500 TL ve altı & 219 & 42,1 \\
\hline & 501 TL-1000 TL & 103 & 19,8 \\
\hline & 1001 TL-1500 TL & 43 & 8,3 \\
\hline & 1501 TL-2000 TL & 45 & 8,7 \\
\hline & 2001 TL-2500 TL & 29 & 5,6 \\
\hline & 2501 TL- 3000 TL & 16 & 3,1 \\
\hline & 3000 TL ve üzeri & 65 & 12,5 \\
\hline \multirow{2}{*}{$\begin{array}{l}\text { Şu anda Yaşadığınız } \\
\text { Yer }\end{array}$} & İlçe veya daha küçük & 194 & 37,3 \\
\hline & ì & 326 & 62,7 \\
\hline \multirow[t]{3}{*}{ Çalışma Durumu } & Çalışan & 115 & 22,1 \\
\hline & Çalışmayan & 68 & 13,1 \\
\hline & Öğrenci & 337 & 64,8 \\
\hline \multirow{2}{*}{$\begin{array}{l}\text { Spor Yapıyor } \\
\text { musunuz? }\end{array}$} & Evet & 238 & 45,8 \\
\hline & Hayır & 282 & 54,2 \\
\hline \multirow{5}{*}{$\begin{array}{l}\text { Kaç Yıldır Spor } \\
\text { Yapıyorsunuz }\end{array}$} & Spor Yapmayan & 282 & 54,2 \\
\hline & $1 \mathrm{yıl}$ ve altı & 70 & 13,5 \\
\hline & $2-5 \mathrm{yll}$ & 70 & 13,5 \\
\hline & $6-9 \mathrm{yll}$ & 37 & 7,1 \\
\hline & 10 yıl ve üzeri & 61 & 11,7 \\
\hline \multirow{3}{*}{$\begin{array}{l}\text { Hangi Düzeyde Spor } \\
\text { Yapıyorsunuz }\end{array}$} & Spor Yapmayan & 282 & 54,2 \\
\hline & Lisanssız & 158 & 30,4 \\
\hline & Lisanlı & 80 & 15,4 \\
\hline
\end{tabular}


Tablo 2. Medeni durum değişkenine göre Bağımsız t-testi

\begin{tabular}{lllll}
\hline & $\begin{array}{l}\text { Vary. Eşitliği } \\
\text { (sig }>\mathbf{0 , 0 5 )}\end{array}$ & F Değeri & $\begin{array}{l}\text { T-Testi } \\
\mathbf{( S i g < 0 , 0 5 )}\end{array}$ & $\begin{array}{l}\text { Anlamlı Fark } \\
\text { Red/Kabul }\end{array}$ \\
\hline RBSÖ-olumsuz & 0,0001 & 11,664 & 0,000 & Kabul \\
\hline RBSÖ-olumlu & 0,956 & 0,003 & 0,029 & Kabul \\
\hline RBSÖ & 0,043 & 4,135 & 0,000 & Kabul \\
\hline MUÖ & 0,222 & 1,493 & 0,005 & Kabul \\
\hline P<0.05 & & & &
\end{tabular}

Tablo 2.1. Medeni durum değişkenine göre grup istatistikleri ve farklılıklar

\begin{tabular}{lll}
\hline & Bekâr & Evli \\
\hline RBSÖ-olumsuz & 3,0459 & 3,4178 \\
\hline RBSÖ-olumlu & 3,3494 & 3,4822 \\
\hline RBSÖ & 0,043 & 4,135 \\
\hline MUÖ & 0,222 & 1,493 \\
\hline
\end{tabular}

Tablo 2. ve Tablo 2.1. de görüldüğü gibi medeni durum değişkenine göre evli katılımcıların ile bekâr katılımcılar göre benlik sayıları ve mutluluk düzeyleri arasında anlamlı fark tespit edilmiştir $(p<0.05)$. RBSÖ toplam puan ortalaması evli katılımcılarda 4,135 iken, bekâr katılımcılarda 0,043 olarak tespit edilmiştir. Mutluluk ölçeğine bakıldığında da evli katılımcıların puan ortalaması 1,493 iken, bekâr katılımcıların 0,222 olarak tespit edilmiştir. Bu sonuçlara göre evli katılımcıların, bekâr katılımcılara göre benlik saygıları ve mutluluk düzeyleri daha yüksek olduğu bulunmuştur.

Tablo 3. Bireylerin Benlik Saygısı ve Mutluluk Düzeylerinin Yaş değişkenine göre ANOVA Analizleri

\begin{tabular}{lllll}
\hline & $\begin{array}{l}\text { Homojenite } \\
(\mathbf{s i g}>\mathbf{0 , 0 5})\end{array}$ & F Değeri & $\begin{array}{l}\text { ANOVA } \\
\text { (Sig<0,05) }\end{array}$ & $\begin{array}{l}\text { Anlamlı Fark } \\
\text { Red/Kabul }\end{array}$ \\
\hline RBSÖ-olumsuz & 0,109 & 8,431 & 0,000 & Kabul \\
\hline RBSÖ-olumlu & 0,564 & 3,303 & 0,038 & Kabul \\
\hline RBSÖ & 0,638 & 7,109 & 0,001 & Kabul \\
\hline MUÖ & 0,990 & 1,894 & 0,151 & Red \\
\hline P<0.05 & & & &
\end{tabular}

Tablo 3.1.Bireylerin Benlik Saygısı ve Mutluluk Düzeylerinin Yaş değişkenine göre Post-Hoc Testleri ve Farklılıklar

\begin{tabular}{llll}
\hline & $\mathbf{1 8 - 2 1}$ yaş & $\mathbf{2 2 - 2 5}$ yaş & $\mathbf{2 6}$ yaş ve üzeri \\
\hline RBSÖ-olumsuz & 2,9846 & - & 3,3241 \\
\hline RBSÖ-olumlu & 3,3215 & - & 3,4574 \\
\hline RBSÖ & 3,1718 & - & 3,3981 \\
\hline MUÖ & - & - & - \\
\hline
\end{tabular}

Tablo 3. ve Tablo 3.1. de görüldüğü gibi yaş değişkenine göre 18-21 yaş aralığındaki katılımcılar ile 26 yaş ve üzeri aralığındaki katılımcılar arasında RBSÖ olumsuz, olumlu ve toplam ölçekte anlamlı farklılık tespit edilmiştir $(p<0,05)$, Mutluluk düzeyleri arasında anlamlı fark tespit edilmemiştir $(p>0,05)$. RBSÖ toplam puan ortalamalarına bakıldığında 26 yaş ve üzeri aralığındaki katılımcıların 3,3981 puan, 18-21 yaş 
aralığındaki katılımcıların ise 3,1718 puan ortalamasına sahip oldukları tespit edilmiştir. Bu sonuca göre; 26 yaş ve üzeri katılımcıların, 18-21 yaş aralığındaki katıııcılara göre benlik saygıları daha yüksek olduğu bulunmuştur.

Tablo 4. Bireylerin Benlik Saygısı ve Mutluluk Düzeylerinin Spor Yapma Durumu değişkenine göre Bağımsız T-Testi Analizleri

\begin{tabular}{lllll}
\hline & $\begin{array}{l}\text { Vary. Eşitliği } \\
\text { (sig }>\mathbf{0 , 0 5 )}\end{array}$ & F Değeri & $\begin{array}{l}\text { T-Testi } \\
\text { (Sig<0,05) }\end{array}$ & $\begin{array}{l}\text { Anlamlı Fark } \\
\text { Red/Kabul }\end{array}$ \\
\hline RBSÖ-olumsuz & 0,393 & 0,732 & 0,000 & Kabul \\
\hline RBSÖ-olumlu & 0,801 & 0,801 & 0,000 & Kabul \\
\hline RBSÖ & 0,995 & 0,000 & 0,000 & Kabul \\
\hline MUÖ & 0,927 & 0,008 & 0,000 & Kabul \\
\hline P<0.05 & &
\end{tabular}

Tablo 4.1. Bireylerin Benlik Saygısı ve Mutluluk Düzeylerinin Spor Yapma Durumu Değişkenine Göre Grup İstatistikleri ve Farklııklar

\begin{tabular}{|l|l|l|}
\hline & Hayır & Evet \\
\hline RBSÖ-olumsuz & 2,9876 & 3,2290 \\
\hline RBSÖ-olumlu & 3,2879 & 3,4630 \\
\hline RBSÖ & 3,1545 & 3,3590 \\
\hline MUÖ & 3,6674 & 3,9588 \\
\hline
\end{tabular}

Tablo 4. ve Tablo 4.1. de görüldüğü gibi spor yapma durumu değişkenine göre spor yapan bireyler ile spor yapmayan bireyler arasında RBSÖ ve mutluluk düzeyi arasında anlamlı fark tespit edilmiştir $(p<0.05)$. RBSÖ toplam puan ortalamasına göre spor yapan katılımcıların 3,3590 puan, spor yapmayan katılımcıların 3,1545 puan ortalamasına sahip oldukları tespit edilmiştir. Mutluluk ölçeği ortalamasına bakıldığında; spor yapan katılımcıların 3,9588 puan, spor yapmayan katılımcıların 3,6674 puan ortalamasına sahip oldukları tespit edilmiştir. Bu iki sonuca göre bakıldığında, spor yapan katııımcıların, spor yapmayan katılımcılara göre benlik saygıları ve mutluluk düzeyleri daha yüksek olduğu bulunmuştur.

Tablo 5. Bireylerin Benlik Saygısı ve Mutluluk Düzeylerinin Gelir Düzeyi Değişkenine Göre ANOVA Analizleri

\begin{tabular}{lllll}
\hline & $\begin{array}{l}\text { Homojenite } \\
(\mathbf{s i g}>\mathbf{0 , 0 5})\end{array}$ & F Değeri & $\begin{array}{l}\text { ANOVA } \\
(\mathbf{S i g}<\mathbf{0 , 0 5})\end{array}$ & $\begin{array}{l}\text { Anlamlı Fark } \\
\text { Red/Kabul }\end{array}$ \\
\hline RBSÖ-olumsuz & 0,002 & 5,038 & 0,000 & Kabul \\
\hline RBSÖ-olumlu & 0,325 & 2,530 & 0,020 & Kabul \\
\hline RBSÖ & 0,020 & 4,286 & 0,000 & Kabul \\
\hline MUÖ & 0,672 & 1,1160 & 0,326 & Red \\
\hline P<0.05 & & & &
\end{tabular}


Tablo 5.1. Bireylerin Benlik Saygısı ve Mutluluk Düzeylerinin Gelir Düzeyi Değişkenine Göre Post-Hoc Testleri ve Farklııklar

\begin{tabular}{llll}
\hline & $\mathbf{5 0 0}$ TL ve altı & $\mathbf{5 0 1}$ TL-1000 TL & $\mathbf{3 0 0 0}$ TL üzeri \\
\hline RBSÖ-olumsuz & 2,9201 & - & 3,4192 \\
\hline RBSÖ-olumlu & 3,3096 & - & 3,5754 \\
\hline RBSÖ & 3,1365 & 3,2319 & 3,5060 \\
\hline MUÖ & - & - & - \\
\hline
\end{tabular}

Tablo 5. ve Tablo 5.1. görüldüğü gibi Gelir Düzeyi değişkenine göre RBSÖ olumlu, olumsuz ve toplam ölçekte anlamlı fark tespit edilmiştir $(p<0.05)$. Mutluluk düzeyinde anlamlı fark tespit edilmemiştir ( $p>0.05)$. 3000 TL ve üzeri gelir düzeyine sahip katılımcıların RBSÖ toplam puan ortalamaları 3,5060, 501 TL-1000TL gelir düzeyine sahip katıımcıların 3,2319, 500TL ve altı gelir düzeyine sahip katılımcıların 3,1365 olarak tespit edilmiştir. 3000 TL ve üzeri gelir düzeyine sahip katıımcıların, 501 TL$1000 \mathrm{TL}$ ve $500 \mathrm{TL}$ ve altı gelir düzeyine sahip katılımcılara göre benlik saygıları daha yüksek olduğu bulunmuştur.

Tablo 6. Bireylerin Benlik Saygısı ve Mutluluk Düzeylerinin Eğitim Seviyeleri Değişkenine Göre ANOVA Analizleri

\begin{tabular}{lllll}
\hline & $\begin{array}{l}\text { Homojenite } \\
\text { (sig }>\mathbf{0 , 0 5})\end{array}$ & F Değeri & $\begin{array}{l}\text { ANOVA } \\
\text { (Sig<0,05) }\end{array}$ & $\begin{array}{l}\text { Anlamlı Fark } \\
\text { Red/Kabul }\end{array}$ \\
\hline RBSÖ-olumsuz & 0,333 & 5,638 & 0,004 & Kabul \\
\hline RBSÖ-olumlu & 0,853 & 2,439 & 0,088 & Red \\
\hline RBSÖ & 0,544 & 4,115 & 0,017 & Kabul \\
\hline MUÖ & 0,706 & 2,554 & 0,079 & Red \\
\hline P<0.05 & & & &
\end{tabular}

Tablo 6.1. Bireylerin Benlik Saygısı ve Mutluluk Düzeylerinin Eğitim Seviyeleri Değişkenine Göre Post-Hoc Testleri ve Farklılıklar

\begin{tabular}{lll}
\hline & Üniversite & Lisansüstü \\
\hline RBSÖ-olumsuz & 3,0547 & 3,5000 \\
\hline RBSÖ-olumlu & - & - \\
\hline RBSÖ & 3,2247 & 3,5463 \\
\hline MUÖ & - & - \\
\hline
\end{tabular}

Tablo 6. ve Tablo 6.1.de görüldüğü gibi katılımcıların eğitim sevileri değişkenine göre RBSÖ olumsuz ve RBSÖ toplam ölçek puan ortalamalarında anlamlı fark tespit edilmiştir $(p<0.05)$. RBSÖ-olumlu ve mutluluk düzeyi arasında anlamlı fark tespit edilmemiştir ( $p>0.05$ ). Lisansüstü düzeyde okuyan ve/veya mezun olan katılımcıların RBSÖ toplam puan ortalaması 3,5463, üniversite okuyan ve/veya mezun olan katılımcıların toplam puan ortalaması 3,2247 olarak tespit edilmiştir. Lisansüstü okuyan ve/veya mezun olan katılımcıların, üniversite okuyan ve/veya mezun olan katılımcılara göre benlik saygıları daha yüksek olduğu bulunmuştur. 
Tablo 7. Bireylerin Benlik Saygısı ve Mutluluk Düzeylerinin Çalışma Durumları Değişkenine Göre ANOVA Analizleri

\begin{tabular}{lllll}
\hline & $\begin{array}{l}\text { Homojenite } \\
(\mathbf{s i g}>\mathbf{0 , 0 5})\end{array}$ & F Değeri & $\begin{array}{l}\text { ANOVA } \\
(\text { Sig<0,05) }\end{array}$ & $\begin{array}{l}\text { Anlaml Fark } \\
\text { Red/Kabul }\end{array}$ \\
\hline RBSÖ-olumsuz & 0,295 & 10,000 & 0,000 & Kabul \\
\hline RBSÖ-olumlu & 0,252 & 2,497 & 0,083 & Red \\
\hline RBSÖ & 0,492 & 6,576 & 0,002 & Kabul \\
\hline MUÖ & 0,061 & 2,351 & 0,096 & Red \\
\hline P<0.05 & & & &
\end{tabular}

Tablo 7.1. Bireylerin Benlik Saygısı ve Mutluluk Düzeylerinin Çalışma Durumu Değişkenine Göre Post-Hoc Testleri ve Farklılıklar

\begin{tabular}{llll}
\hline & Öğrenci & Çalışmayan & Çalışan \\
\hline RBSÖ-olumsuz & 2,9889 & 3,2463 & 3,3304 \\
\hline RBSÖ-olumlu & - & - & - \\
\hline RBSÖ & 3,1866 & - & 3,4019 \\
\hline MUÖ & - & - & - \\
\hline
\end{tabular}

Tablo 7. ve Tablo 7.1. görüldüğü gibi katılımcıların çalışma durumu değişkenine göre RBSÖ olumsuz ve RBSÖ toplam ölçek boyutunda anlamlı fark tespit edilmiştir $(p<0.05)$. RBSÖ olumlu ve mutluluk ölçeğinde anlamlı fark tespit edilmemiştir (p>0.05). Çalışan katılımcıların 3,3304, çalışmayan katılımcıların 3,2463, öğrenci katılımcılarının 2,9889 olarak RBSÖ-olumsuz puan ortalaması tespit edilmiştir. Öğrenci olan katılımcıların, çalışmayan ve çalışan katıımcılara göre benlik saygıları daha düşük olduğu bulunmuştur.

Tablo 8. Bireylerin Benlik Saygısı ve Mutluluk Düzeylerinin Spor Yapma Süreleri Değişkenine Göre ANOVA Analizleri

\begin{tabular}{lllll}
\hline & $\begin{array}{l}\text { Homojenite } \\
(\mathbf{s i g}>\mathbf{0 , 0 5})\end{array}$ & F Değeri & $\begin{array}{l}\text { ANOVA } \\
(\text { Sig<0,05) }\end{array}$ & $\begin{array}{l}\text { Anlamlı Fark } \\
\text { Red/Kabul }\end{array}$ \\
\hline RBSÖ-olumsuz & 0,662 & 4,907 & 0,001 & Kabul \\
\hline RBSÖ-olumlu & 0,519 & 5,982 & 0,000 & Kabul \\
\hline RBSÖ & 0,686 & 6,539 & 0,000 & Kabul \\
\hline MUÖ & 0,534 & 5,775 & 0,000 & Kabul \\
\hline P<0.05 & & & &
\end{tabular}

Tablo 8.1. Bireylerin Benlik Saygısı ve Mutluluk Düzeylerinin Spor Yapma Süreleri Değişkenine Göre Post-Hoc Testleri ve Farklılıklar

\begin{tabular}{lllll}
\hline & Spor yapmayan & 1 yıl ve altı & $\mathbf{6 - 9}$ yıl & 10 yıl ve üzeri \\
\hline RBSÖ-olumsuz & 2,9876 & - & - & 3,3934 \\
\hline RBSÖ-olumlu & 3,2879 & - & - & 3,5803 \\
\hline RBSÖ & 3,1545 & 3,2206 & - & 3,4973 \\
\hline MUÖ & 3,6674 & - & 4,0541 & 4,1279 \\
\hline
\end{tabular}

Tablo 8. ve Tablo 8.1. de görüldüğü gibi spor yapma süreleri değişkenine göre RBSÖ olumlu, olumsuz, toplam ölçek ve mutluluk ölçeğinde anlamlı fark tespit edilmiştir $(p<0.05) .10$ yıl ve üzeri süre spor yapan katılımcıların RBSÖ toplam puan ortalaması 
3,4973, 1 yıl ve altı süre spor yapan katılımcıların 3,2206, spor yapmayan katılımcıların 3,1545 olarak tespit edilmiştir. 10 yıl ve üzeri süre spor yapan katılımcıların mutluluk ölçeği toplam puan ortalaması 4,1279, 6-9 yıl arası süreyle spor yapan katılımcıların 4,0541, spor yapmayan katılımcıların 3,6674 olarak tespit edilmiştir. 10 yıl ve üzeri süre spor yapan katılımcılar ile 6-9 yıl arası süreyle spor yapan katılımcıların, 1 yıl ve altı veya spor yapmayan katılımcılara göre benlik saygıları ve mutluluk düzeyleri daha yüksek olduğu bulunmuştur.

Tablo 9. Bireylerin Benlik Saygısı ve Mutluluk Düzeylerinin Sporda Profesyonellik Düzeyleri Değişkenine Göre ANOVA Analizleri

\begin{tabular}{lllll}
\hline & $\begin{array}{l}\text { Homojenite } \\
(\mathbf{s i g}>\mathbf{0 , 0 5})\end{array}$ & F Değeri & $\begin{array}{l}\text { ANOVA } \\
(\mathbf{S i g}<\mathbf{0 , 0 5})\end{array}$ & $\begin{array}{l}\text { Anlamlı Fark } \\
\text { Red/Kabul }\end{array}$ \\
\hline RBSÖ-olumsuz & 0,197 & 7,780 & 0,000 & Kabul \\
\hline RBSÖ-olumlu & 0,571 & 9,144 & 0,000 & Kabul \\
\hline RBSÖ & 0,950 & 10,184 & 0,000 & Kabul \\
\hline MUÖ & 0,725 & 9,189 & 0,000 & Kabul \\
\hline P<0.05 & & &
\end{tabular}

Tablo 9.1. Bireylerin Benlik Saygısı ve Mutluluk Düzeylerinin Sporda Profesyonellik Düzeyleri Değişkenine Göre Post-Hoc Testleri ve Farklılıklar

\begin{tabular}{llll}
\hline & Spor yapmayan & Lisanssız & Lisanslı \\
\hline RBSÖ-olumsuz & 2,9876 & 3,1693 & 3,3469 \\
\hline RBSÖ-olumlu & 3,2879 & 3,4316 & 3,5250 \\
\hline RBSÖ & 3,1545 & 3,3150 & 3,4458 \\
\hline MUÖ & 3,6674 & 3,9127 & 4,0500 \\
\hline
\end{tabular}

Tablo 9. ve Tablo 9.1. de görüldüğü gibi katılımcıların sporda profesyonellik düzeyleri değişkenine göre RBSÖ olumsuz, olumlu, toplam ölçek ve Mutluluk ölçeğinde anlamlı fark tespit edilmiştir $(p<0.05)$. Lisanlı olarak spor yapan katılımcıların RBSÖ toplam puan ortalaması 3,4458 , lisansız spor yapan katılımcıların 3,3150 ve spor yapmayan katıımcıların 3,1545 olarak tespit edilmiştir.

Lisanlı olarak spor yapan katılımcıların mutluluk ölçeği puan ortalaması 4,0500 , lisansız spor yapan katılımcıların 3,9127 ve spor yapmayan katılımcıların 3,6674 olarak tespit edilmiştir. Lisanslı ve lisanssız olarak spor yapan katılımcıların spor yapmayan katıııcılara göre benlik saygıları ve mutluluk düzeyleri daha yüksek olduğu bulunmuştur.

\section{Tartışma ve Sonuç}

Araştırmamızda; cinsiyet değişkenine göre benlik saygısı üzerinde anlamlı bir fark tespit edilmemiştir. Benzer şekilde, Çiftçi (2018)' de "Ergenlerin benlik saygısı düzeylerinin karşılaştırılması, meslek yüksekokulu ve meslek lisesi öğrencileri üzerine bir inceleme" adlı çalışmasında cinsiyet değişkenine göre anlamlı bir fark 
tespit edilememiştir. Eroğlu ve ark., (2019) yaptıkları çalışmalarında rosenberg benlik saygısı ölçeği ile cinsiyet, medeni durum, eğitim durumu, çalışma durumu gibi özelliklerde anlamlı fark tespit etmemiştir. Aslan ve ark., (2017) çalışmalarında cinsiyet değişkenine göre anlamlı bir fark elde etmişlerdir. Türker ve ark., (2018) çalışmalarında bireylerin yaş, cinsiyet, spor yapma yılı ve ailede spor yapan değişkenliklerine göre benlik saygısı ile ilişkili anlamlı fark tespit edememişleridir. Aksoy ve ark., (2017) yaptıkları çalışmalarında örneklem grubu olarak ele alınan öğrencilerin mutluluk ve alçakgönüllülük ölçeklerinden aldıkları puanlar incelendiğinde cinsiyet değişkenine göre anlamlı bir farklılık göstermediği bulunmuştur. Karakoç, Çoban ve Konar (2012) tarafından "işitme engelli milli sporcular ile spor yapmayan işitme engellilerin benlik saygısı düzeylerinin karşılaştırılması" isimli çalışmalarında spor yapan işitme engellilerin, spor yapmayan işitme engellilere göre benlik saygısı düzeylerinin daha yüksek olduğunu tespit etmişlerdir. Spor duygusal anlamda olumlu etki sağladığını tespit etmişlerdir. Araştırmamızda; gelir düzeyine göre anlamlı bir fark tespit edilmiştir. Balat ve Akman (2004) yılında yapmış oldukları "Farklı sosyo-ekonomik düzeydeki lise öğrencilerinin benlik saygısı düzeylerinin incelenmesi" adlı çalışmalarında sosyo-ekonomik gelir değişkenine göre anlamlı bir fark tespit edilememiştir. Araştırmamızda spor yapan bireylerini spor yapmayan bireylere göre daha yüksek benlik kavramına sahip oldukları tespit edilmiştir. Çalışmamızı destekler nitelikte olan çalışmada, Özgeylani (1993), tarafından liseli erkek sporcu ve sporcu olmayanların benlik kavramlarını karşıllaşıırdığı araştırmasında, sporcuların daha yüksek benlik kavramına sahip olduklarını ortaya koymuştur. Çalışmamızda spor yapan bireyler, spor yapmayan bireylere göre daha mutlu ve benlik saygısı düzeyi yüksek çıkmıştır. Çalışmamızı destekler nitelikte olan, Aslan ve ark., (2017) çalışmalarında spor aktivitesine katıımın bedensel engelli erişkinlerde benlik saygısını geliştirdiğini tespit etmişlerdir. Başar ve Sarı (2018) de yapmış oldukları çalışma bulgularına göre düzenli spor yapanlar ile yapmayanlar arasında depresyon/mutluluk, mutluluk ve psikolojik iyi oluş puanlarında istatistiksel olarak anlamlı bir farkın olduğu tespit edilmiştir. 


\begin{tabular}{|l|l|l|l|l|}
\hline \hline & MUÖ & $\begin{array}{l}\text { RBSÖ } \\
\text { TOPLAM }\end{array}$ & $\begin{array}{l}\text { RBSÖ } \\
\text { Olumsuz }\end{array}$ & $\begin{array}{l}\text { RBSÖ } \\
\text { Olumlu }\end{array}$ \\
\hline Cinsiyet & - & - & - & - \\
\hline Yaşadığı Yer & - & - & - & - \\
\hline Yaş Aralığı & - & $\mathrm{X}$ & $\mathrm{X}$ & $\mathrm{X}$ \\
\hline Gelir Düzeyi & - & $\mathrm{X}$ & $\mathrm{X}$ & $\mathrm{X}$ \\
\hline Eğitim Seviyeleri & - & $\mathrm{X}$ & $\mathrm{X}$ & - \\
\hline Çalışma Durumları & - & $\mathrm{X}$ & $\mathrm{X}$ & - \\
\hline Medeni Durum & $\mathrm{X}$ & $\mathrm{X}$ & $\mathrm{X}$ & $\mathrm{X}$ \\
\hline Spor Yapma Durumu & $\mathrm{X}$ & $\mathbf{X}$ & $\mathbf{X}$ & $\mathbf{X}$ \\
\hline Spor Yapma Süreleri & $\mathbf{X}$ & $\mathbf{X}$ & $\mathbf{X}$ & $\mathbf{X}$ \\
\hline $\begin{array}{l}\text { Sporda Profesyonellik } \\
\text { Düzeyleri }\end{array}$ & $\mathbf{X}$ & $\mathbf{X}$ & $\mathbf{X}$ & $\mathbf{X}$ \\
\hline
\end{tabular}

Çalışmamızın amacı bireylerin spor yapma durumları ile benlik saygısı ve mutluluk düzeyleri arasındaki ilişkiyi incelemek olduğundan dolayı, örneklem grubundan elde edilen bulgular ışığında, bireylerin:

- Spor yapiyor olmaları,

- Spor ile uğraşma sürelerinin artması,

- Sporda profesyonellik düzeylerinin artması,

Benlik saygısı ve mutluluk düzeyleri üzerinde olumlu bir etkiye sahiptir denilebilmektedir.

\section{Kaynaklar}

Aksoy, A.B., Güngör Aytar, A., Kaytez, N. (2017). Üniversite öğrencilerinin mutluluk ve alçakgönüllülük düzeylerinin bazı değişkenlere göre incelenmesi. Kastamonu Eğitim Dergisi. 25(3), 1119-1132.

Aslan, Ş., Baş Aslan, U., Uyan, A. (2017). Spor yapma durumlarına göre bedensel engelli bireylerin benlik saygısının karşılaştırılması. Journal of Human Sciences. 14(4): 4032-4040.

Balat, G.U., Akman, B. (2004). "Farklı sosyo-ekonomik düzeydeki lise öğrencilerinin benlik saygısı düzeylerinin incelenmesi”. Fırat Üniversitesi Sosyal Bilimler Dergisi. 14(2): 175-183.

Başar, S., Sarı, İ. (2018). Düzenli egzersizin depresyon, mutluluk ve psikolojik iyi oluş üzerine etkisi. İnönü Ün. Beden Eğitimi ve Spor Bilimleri Dergisi. 5(3): 25-34.

Çiftçi, H. (2018). "Ergenlerin benlik saygısı düzeylerinin karşıllaştıııması meslek yüksekokulu ve meslek lisesi öğrencileri üzerine bir inceleme" Electronic journal of social sciences. 17(68): 1648-1665. 
Çoknaz, H. (1998). "Takım ve bireysel spor antrenörlerinin iş doyumu düzeylerinin karşılaştırıması" Yüksek Lisans Tezi. Abant İzzet Baysal Üniversitesi Sosyal Bilimler Enstitüsü. Beden Eğitimi Ve Spor Yönetimi Bilimleri Anabilim Dalı.

Çuhadaroğlu, F. (1986). Adolesanlarda benlik saygısı. Yayımlanmamış Uzmanlık Tezi. Hacettepe Üniversitesi Tıp Fakültesi. Psikiyatri ABD. Ankara.

Demirci, İ. (2017). Huzurlu ve mutlu yaşamın değerler ve karakter güçleri bağlamında karma bir araştırmayla incelenmesi (Doktora tezi). Marmara Üniversitesi Eğitim Bilimleri Enstitüsü.

Diener, E., Chan, M.Y.(2011). Happy people live longer: subjective well-being contributes to health and longevity. Applied Psychology. 3(1): 1-43.

Diener, E., Oishi, S. Lucas, R.E. (2003). Personality, culture and subjective wellbeing: emotional and cognitive evaluations of life. Annual Review of Psychology. 54: 403-425.

Eroglu, M. Z., Sertcelik, S., Gunduz, A. \& Demirkol, M. E. (2019) [Self-esteem and quality of life in bariatric surgery candidates]. Anatolian Journal of Psychiatry. 20(1): 20-28.

Guindon, M.H. (2009). What is self-esteem? M. H. Guindon (Ed.), Self-esteem across the lifespan: Issues and interventions (pp.3-25). New York: Taylor \& Francis.

Karakoç, Ö., Çoban, B., \& Konar, N. (2012). İşitme engelli milli sporcular ile spor yapmayan işitme engellilerin benlik saygısı düzeylerinin karşılaştırılması. Selçuk Üniversitesi Beden Eğitimi ve Spor Bilim Dergisi. 14(1): 12-17.

Koydemir, S., Mısır, S. (2015). Benlik kurguları ve mutluluk: deneysel bir hazırlama çalışması. Türk Psikolojik Danışma ve Rehberlik Dergisi. 5(44): 49-60.

Lyubomirsky, S. (2001). Why are some people happier than others? The role of cognitive and motivational processes in well-being. American Psychologist. 56: 239- 249.

Özgeylani, F.H. (1993). Lise düzeyindeki erkek sporcuların ve sporcu olmayanların benlik kavramları ve beden imgeleri. Yüksek Lisans Tezi. O.D.T.Ü. Sosyal Bilimler Enstitüsü.

Rosenberg, M. (1965). Society and the adolescent self-image. New Jersey: Princeton University Press.

Rosenberg, M. (1979). Conceiving the self. New York: Basic Books.

Türker, A., Er, Y., Yavuz Eroğlu, S., Şentürk, A., Durmaz, M. (2018). Spor Yapan Bireylerin Sosyal Görünüş Kaygısı ve Benlik Saygısının İncelenmesi. Muş Alparslan Üniversitesi Uluslararası Spor Bilimleri Dergisi. 2(1): 8-15. 